ORIGINAL ARTICLE

\title{
Assessment of the impact of COVID-19 pandemic on emotional and nutritional status of university athletes
}

\author{
Gökmen Özen $^{\mathrm{ABCD}}$, Günay Eskici ${ }^{\mathrm{ABDE}}$, Hüseyin Ö. Yurdakul ${ }^{\mathrm{ADE}}$, Hürmüz Koç ${ }^{\mathrm{ACDE}}$ \\ Çanakkale Onsekiz Mart University, Çanakkale, Turkey
}

Authors' Contribution: A - Study design; B - Data collection; C - Statistical analysis; D - Manuscript Preparation; E - Funds Collection

\begin{abstract}
Background and Study Aim

Material and

Methods

The current study was carried out to analyze the impact of COVID-19 pandemic on the emotional state and nutritional behavior of university athletes.

This research was carried out during the first wave of COVID-19 in Turkey. A total of 334 (162 female and 172 male) athletes who are undergraduate students in the faculties of sports sciences of universities participated in the study. Their mean age was $21.46 \pm 3.7$. The Emotional Eating Scale (EES) was used to determine the nutritional behavior of the participants and The Profile of Mood States (POMS) scale was used to determine their emotional state. The Chi-square and Cross-tabulation tests were used for the statistical analysis of categorical variables. Mann Whitney $\mathrm{U}$ test was used for the analysis of continuous variables, and Spearman Sequence Correlation test protocols were used for correlation analysis.

Results: $\quad$ The results of the statistical analysis revealed that there was a significant increase in the amount of fluid consumption of elite athletes. There was a significant relationship between negative mood and emotional eating sub-assessment $(p<0.05)$. However, it was found that there was no significant difference between total and subscale scores of amateur and elite athletes $(p>0.05)$.

Conclusions As a result of the research, it was seen that elite and amateur athletes did not have a significant difference in emotional eating and mood status, except for the amount of fluid consumption. The increase in negative emotions of university athletes is an important factor that increased their emotional eating behavior.

Keywords: athlete, behavior, COVID-19, emotion, nutrition.
\end{abstract}

\section{Introduction}

The new type of coronavirus disease (COVID-19), which has recently become one of the biggest problems in the world, was first detected in the Wuhan region of China in December 2019. Coronavirus spread to all over the world in a very short time after passing from one person to another as a result of the mutation it suffered and caused a pandemic [1]. According to the World Health Organization (WHO) data, more than 2 million people got this disease in April 2020 and approximately 200, 000 people died due to the complications of the COVID-19 in the human body. According to the WHO reports, the number of people who are ill and die due to illness continues to increase day by day [2].

Since a drug or vaccine that still provides a definitive treatment against COVID-19 disease has not been developed, the epidemic continues and has caused the health system to come to a clogging point in many countries due to the increasing number of patients. Under these conditions, it is stated that providing personal hygiene and social isolation in the society as the most important precaution against disease [3]. Within the scope of social isolation, people are asked not to leave the house, except in compulsory situations, in many countries of the world and legal regulations are made accordingly. In many countries within the scope of social isolation practices,

\footnotetext{
๑) Gökmen Özen, Günay Eskici, Hüseyin Ö. Yurdakul,

Hürmüz Koç, 2021

doi:10.15561/20755279.2021.0106
}

basic education institutions and universities have started from formal education to distance education, sports competitions have been stopped and training facilities have been closed. Today, sports activities are among the most common recreational activities for children and young people. Limiting participation in sports activities and not leaving the house for social isolation will result in a significant decrease in the level of physical activity for these children and adolescents $[4,5]$.

Low level of physical activity is a condition that causes health problems both physically and psychologically. Therefore, the negative effects of COVID-19 disease are likely to decrease the physical activity level in young people during the social isolation period, limiting the daily life and social life [6,7]. Nutritional habits and psychological state are very effective variables in terms of human health. It is a very strong possibility that sudden changes in lifestyle lead to important changes in the nutritional and emotional conditions of young people during the social isolation period [8]. In this regard, ensuring the normalization of daily life after pandemics is not only dependent on the COVID-19 treatments but also the effects of this social isolation period on people's habits and psychological state of life.

Traumatic events such as wars, natural disasters, and epidemics in human life and minor accidents and diseases occurring in our immediate environment cause marked changes in emotional state. The youth period is considered to be the years when the emotional fluctuations are greatest 
in human life. In this regard, COVID-19 pandemic and measures of social isolation will have serious effects on the emotions of young individuals $[9,10]$. Scientific studies show that the psychological state of people is a determinant of life habits. One of the most decisive life habits on health is eating habits. While healthy nutrition behaviors have positive effects on health protection and disease prevention, unhealthy nutrition behaviors affect metabolism both physically and physiologically, causing health deterioration and a more fragile structure against diseases [8]. In the light of this information, our study aimed to examine the emotional state and nutritional behavior of university athletes in the COVID-19 pandemic and social isolation period.

\section{Materials and Methods}

\section{Participants.}

A total of 334 [162 (48.5\%) female and 172 (51.5\%) male] athletes who are undergraduate students in the faculties of sports sciences of the universities participated in the study. The mean age of participants was 21.49 \pm 3.7 years old. Of the 334 participants, 196 (58.7\%) were amateur and $138(41.3 \%)$ were elite athletes. The participants were regular training athletes before the COVID-19 pandemic process.

\section{Research Design.}

This research was carried out during the first wave of COVID-19 in Turkey in April and May of 2020. This research is a descriptive research that collects data with the survey method. The research was carried out following social isolation rules by using information forms and measurement tools prepared by the researchers in the digital environment and transmitted to the participants over the internet. In the same way, informed consent forms were obtained from the volunteer participants who agreed to participate in the research. The research was carried out by adhering to the ethical principles stated in the Helsinki Declaration.

\section{Data Collection.}

Anthropometric measurement standards were written and visually reported to the participants for their height and body weight measurements. Body weight and height measurement results, which the participants measured at home under these standards, were accepted.

\section{The Profile of Mood States (POMS)}

POMS scale was developed by McNair, Lorr, and Droppleman [11] to determine the emotional state of the participants and The Turkish version of POMS scale that adapted to Turkish and Turkish culture by Selvi et al. [12] was used in this study. The Turkish form of the POMS scale consists of 58 items that describe the current emotional state of individuals. The results consistently indicated the following 6 dimensions: "depressiondejection" -15 , "tension-anxiety" -9 , "anger-hostility" -12 , "confusion-bewilderment" -7 , "fatigue-inertia" -7, and "vigor-activity" -8. POMS scale is five-point Likert type as 0- never, 1- Very low, 2- Moderate, 3- Quite, and 4- Extreme. According to the scores obtained from POMS, the scores obtained from the vigor-activity subscale indicate a positive mood, while scores from other subscales indicate a negative mood. In addition, the total score average of the five sub-dimensions other than the vigor-activity sub-dimension is considered as an indicator of negative mood. Selvi et al. [12]reported that the reliability coefficient of the scale was in the range of 0.81-0.91.

\section{Emotional Eating Scale (EES)}

Emotional Eating Scale (EES) developed by Bilgen (2018) was used to examine the emotional eating behaviors of the participants [13]. The scale consists of 30 items and four sub-dimensions. The results consistently indicated the following 4 dimensions: "Eating When Nervous (EWN)" - 11, "Eating to cope with Negative Emotions (EEN)" - 10, "Self-Control (SC)" - 6 and "Control Against Stimuli (CAS ) "- 3. The reliability coefficients of the scale sub-dimensions were found to be 0.63-0.94 and general 0.96. The answers given to the scale items are five-point Likert type as 1-Never, 2-Rarely, 3-Sometimes, 4-Frequently, and 5- Always, and a minimum of 30 points and a maximum of 150 points can be obtained from the scale. It was stated in the scale scoring that items 26,28 , and 29 should be inverted. The high score obtained from the scale indicates that emotional eating tendencies and behaviors are high.

Statistical Analysis.

The data were analyzed using the SPSS 22.0 statistical analysis program. The results of statistical analysis were present as frequency (n) and percentage (\%) for categorical variables and as mean \pm standard deviation $(M$ \pm SD) values for continuous variables. Normality analyzes of the distribution of the research data were evaluated using the Kolmogorov Smirnov test. The normality test revealed that the data did not show normal distribution. In statistical analysis, cross-table and Chi-square tests were used for the analysis of categorical variables, Mann Whitney $U$ test was used in the analysis of continuous variables, and Spearman Sequence Correlation test protocols were used for correlation analysis. The level of statistical significance was set at 0.05 .

\section{Results}

The physical characteristics of the participants are presented in Table 1. When the physical characteristics of the athletes were examined, there was no statistically significant difference between amateur and elite athletes in terms of age, height, body weight, and BMI ( $p>0.05$ ).

The general nutritional behaviours of the participants during the social isolation period are given in Table 2 . The results of the analysis of the nutritional behaviors of the athletes during the social isolation period showed that there was no statistically significant relationship between food consumption, the number of daily meals, the use of supplements, and the immune-boost food intake rates of the amateur and elite athletes ( $p>0.05)$. However, a statistically significant relationship was found between their fluid consumption status. When the fluid consumption rates were compared, it was determined that elite athletes had an increase in fluid consumption, but not in amateur 
athletes $\left(X^{2}=3657, \mathrm{p}=0.04\right)$. When the general rates of fluid consumption of athletes were analyzed, it was found that there were statistically significant differences between daily meal number, body weight status, amount of fluid consumption and supplement consumption rates $(\mathrm{p}<0.05)$. It was determined that there was no statistically significant relationship in the general diet and immuneboost food intake preference rates of the participants $(\mathrm{p}>$ $0.05)$.

The macronutrient consumption rates of the participants in the COVID-19 social isolation period are presented in Figure 1. When these rates were analyzed, it was found that the amount of carbohydrate and fat consumption in athletes mostly decreased or did not change but protein consumption increased.
When we examined the supplements used by the athletes participating in the study to strengthen their immunity against COVID-19, it was found that they used the most supplements containing vitamin D, multivitamins, and omega-3, respectively.

Analysis of the POMS scores of the participants in the social isolation period is presented in Table 3. It was found that there was no statistically significant difference between the POMS total and seven sub-dimension score averages of the amateur and elite athletes in the social isolation period of the athletes ( $\mathrm{p}>0.05)$.

The analysis of the EES scores of the participants during the social isolation period is presented in Table 4. It was found that there was no statistically significant difference between the EES total and subscale score averages of amateur and elite athletes in the social

Table 1. Analysis of the general physical characteristics of athletes

\begin{tabular}{lllllll}
\hline Variables & Group & Min & Max & M \pm Sd & t & p \\
\hline \multirow{2}{*}{ Age (year) } & Amateur & 18 & 40 & $21.26 \pm 3.29$ & \multirow{2}{*}{0.453} & 0.15 \\
& Elite & 18 & 35 & $21.86 \pm 4.26$ & & 0.22 \\
Height $(\mathrm{cm})$ & Amateur & 155 & 197 & $172.4 \pm 9.12$ & \multirow{2}{*}{1.226} & \\
& Elite & 150 & 202 & $174.1 \pm 9.97$ & & 0.10 \\
\multirow{2}{*}{ Weight $(\mathrm{kg})$} & Amateur & 43 & 100 & $66.67 \pm 12.43$ & \multirow{2}{*}{0.629} & \\
& Elite & 45 & 112 & $68.52 \pm 15.06$ & & 0.73 \\
\hline
\end{tabular}

Table 2. Analysis of nutrition habits of athletes during social isolation period.

\begin{tabular}{|c|c|c|c|c|c|}
\hline \multirow{2}{*}{ Variables } & Amateur & Elite & Total & \multirow{2}{*}{$\mathrm{X}^{2}$} & \multirow{2}{*}{$p$} \\
\hline & $n(\%)$ & n (\%) & n (\%) & & \\
\hline \multicolumn{6}{|l|}{ Food Consumption } \\
\hline Unchanged & $66(33.7)$ & 51 (37.) & $117(35.0)$ & \multirow{3}{*}{0.403} & \multirow{3}{*}{0.81} \\
\hline Increased & $70(35.7)$ & $46(33.3)$ & $116(34.7)$ & & \\
\hline Decreased & $60(30.6)$ & $41(29.7)$ & $101(30.3)$ & & \\
\hline \multicolumn{6}{|l|}{ Number of meals per day } \\
\hline Two meals & $53(27.0)$ & $43(31.2)$ & $96(28.7) t$ & \multirow{3}{*}{0.671} & \multirow{3}{*}{0.71} \\
\hline Three meals & $101(51.5)$ & $67(48.6)$ & $168(50.3) \ddagger$ & & \\
\hline Four and above meals & $42(21.4)$ & $28(20.3)$ & $70(21.0) t$ & & \\
\hline \multicolumn{6}{|l|}{ Daily Fluid Consumption } \\
\hline Unchanged & $95(48.5)^{*}$ & 55 (39.9) & 150 (44.9)t & \multirow{3}{*}{3.637} & \multirow{3}{*}{$0.04^{*}$} \\
\hline Increased & $72(36.7)$ & $65(47.1)^{*}$ & $137(41.0) \ddagger$ & & \\
\hline Decreased & $29(14.8)$ & $18(13.0)$ & $47(14.1) €$ & & \\
\hline \multicolumn{6}{|l|}{ Body weight status } \\
\hline Decreased & $29(14,8)$ & $20(20.2)$ & 49(14.7)t & \multirow{3}{*}{1.083} & \multirow{3}{*}{0.582} \\
\hline Unchanged & $83(42.3)$ & $66(47.8)$ & 149(44.6)t & & \\
\hline Increased & $84(49.2)$ & $52(37.7)$ & 136(40.7)t & & \\
\hline \multicolumn{6}{|l|}{ Supplementation consumption } \\
\hline Yes & $34(17.3)$ & $32(23.2)$ & $66(19.8) t$ & \multirow{2}{*}{1.743} & \multirow{2}{*}{0.12} \\
\hline No & $162(80.2)$ & $106(76.8)$ & $268(80.2) t$ & & \\
\hline \multicolumn{6}{|l|}{ Immune-Boosting Food Intake } \\
\hline Yes & $104(53.1)$ & $76(55.1)$ & 180 (53.9) & \multirow{2}{*}{0.132} & \multirow{2}{*}{0.40} \\
\hline No & $92(46.9)$ & $62(44.9)$ & $154(46.1)$ & & \\
\hline
\end{tabular}

Note: ${ }^{*} p<0.05, \mathrm{t}: \mathrm{p}<0.0 .5$ significant difference between total rates. 
$100 \%$

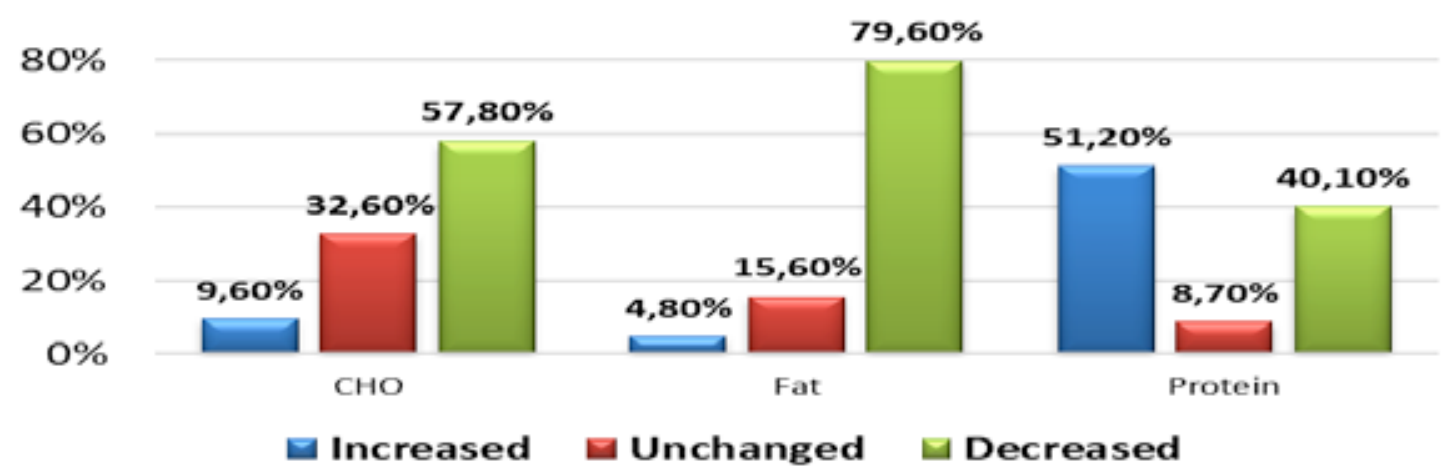

Figure 1. Athletes' macronutrient intake ratio for COVID-19

\section{Immune System Supplements}

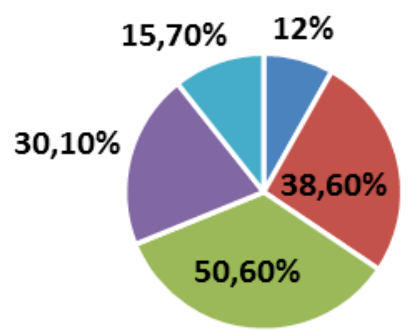

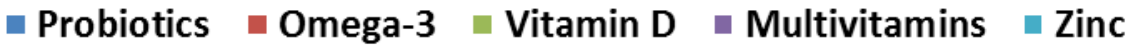

Figure 2. Supplements used by athletes to strengthen the immune system

Table 3. Analysis of mood profiles of the athletes during the social isolation period

\begin{tabular}{|c|c|c|c|c|c|}
\hline \multirow{2}{*}{$\begin{array}{l}\text { Mood States Profile Scale } \\
\text { Sub-dimensions }\end{array}$} & \multirow{2}{*}{$\begin{array}{l}\text { Amateur } \\
\mathrm{M} \pm \mathrm{Sd}\end{array}$} & \multirow{2}{*}{$\begin{array}{l}\text { Elite } \\
\mathrm{M} \pm S d\end{array}$} & \multirow{2}{*}{$\begin{array}{l}\text { Total } \\
\mathrm{M} \pm \mathrm{Sd} \\
\end{array}$} & \multirow{2}{*}{$z$} & \multirow{2}{*}{$p$} \\
\hline & & & & & \\
\hline Tension & $13.52 \pm 7.00$ & $14.85 \pm 7.52$ & $14.07 \pm 7.23$ & 1.648 & 0.10 \\
\hline Depression & $25.32 \pm 13.15$ & $26.42 \pm 12.53$ & $25.77 \pm 12.89$ & 0.770 & 0.44 \\
\hline Anger & $16.74 \pm 12.12$ & $18.08 \pm 11.52$ & $17.29 \pm 11.88$ & 1.015 & 0.31 \\
\hline Vigor & $10.41 \pm 6.50$ & $11.07 \pm 6.21$ & $10.69 \pm 6.38$ & 0.922 & 0.35 \\
\hline Fatigue & $12.53 \pm 7.92$ & $13.04 \pm 7.00$ & $12.74 \pm 7.54$ & 0.611 & 0.54 \\
\hline Confusion & $9.51 \pm 4.90$ & $10.51 \pm 5.08$ & $9.92 \pm 4.99$ & 1.816 & 0.07 \\
\hline Total POMS score & $67.20 \pm 41.16$ & $71.83 \pm 40.26$ & $69.11 \pm 40.80$ & 1.021 & 0.31 \\
\hline
\end{tabular}

Table 4. Analysis of emotional eating status of the athletes during the social isolation period

\begin{tabular}{|c|c|c|c|c|c|}
\hline \multirow{2}{*}{$\begin{array}{l}\text { Emotional Eating Scale } \\
\text { Sub-dimensions }\end{array}$} & \multirow{2}{*}{$\begin{array}{l}\text { Amateur } \\
\mathrm{M} \pm \mathrm{Sd}\end{array}$} & \multirow{2}{*}{$\begin{array}{l}\text { Elite } \\
M \pm S d\end{array}$} & \multirow{2}{*}{$\begin{array}{l}\text { Total } \\
\mathrm{M} \pm \mathrm{Sd}\end{array}$} & \multirow{2}{*}{$z$} & \multirow{2}{*}{$\mathbf{p}$} \\
\hline & & & & & \\
\hline EWN & $25.32 \pm 13.15$ & $23.03 \pm 9.03$ & $22.15 \pm 8.70$ & -1.496 & 0.13 \\
\hline ENE & $18.33 \pm 7.26$ & $19.80 \pm 7.70$ & $18.49 \pm 7.47$ & -2.345 & 0.06 \\
\hline SC & $14.61 \pm 4.75$ & $14.85 \pm 5.02$ & $14.71 \pm 4.85$ & -0.401 & 0.69 \\
\hline CAS & $8.35 \pm 2.76$ & $8.46 \pm 2.64$ & $8.39 \pm 2.71$ & -0.546 & 0.58 \\
\hline Total EES score & $62.83 \pm 19.47$ & $66.15 \pm 21.62$ & $64.20 \pm 20.422$ & -1.265 & 0.21 \\
\hline
\end{tabular}

Note: EES: Emotional Eating Scale, EWN: Eating When Nervous, ENE: Eating to cope with Negative Emotions, SC: Self Control, CAS: Control Against Stimuli 
Table 5. The relationship between emotional profile and emotional eating status of the athletes' social isolation period

\begin{tabular}{|c|c|c|c|c|c|c|}
\hline Variables & & EWN & ENE & SC & CAS & Total EES \\
\hline \multirow{2}{*}{ Tension } & $r$ & $.333 * *$ & $.295 * *$ & $.220 * *$ & $.121 *$ & $.318 * *$ \\
\hline & $p$ & .000 & .000 & .000 & .027 & .000 \\
\hline \multirow{2}{*}{ Depression } & r & $.340 * *$ & $.279 * *$ & $.253^{* *}$ & $.137^{*}$ & $.327 * *$ \\
\hline & $p$ & .000 & .000 & .000 & .012 & .000 \\
\hline \multirow{2}{*}{ Anger } & r & $.292 * *$ & $.268 * *$ & $.227^{* *}$ & $.131^{*}$ & $.291 * *$ \\
\hline & $p$ & 000 & .000 & .000 & .017 & .000 \\
\hline \multirow{2}{*}{ Vigor } & r & $-.118 * *$ & -.031 & -.061 & -.026 & -.078 \\
\hline & $p$ & .000 & .567 & .265 & .633 & .157 \\
\hline \multirow{2}{*}{ Fatigue } & r & $.395^{* *}$ & $.303^{* *}$ & $.292 * *$ & $.169 * *$ & $.375^{* *}$ \\
\hline & $p$ & .000 & .000 & .000 & .002 & .000 \\
\hline \multirow{2}{*}{ Confusion } & r & $.224 * *$ & $.243 * *$ & $.175^{* *}$ & .038 & $.232 * *$ \\
\hline & $p$ & 000 & .000 & .001 & .485 & .000 \\
\hline \multirow{2}{*}{ Total POMS } & $r$ & $.365^{* *}$ & $.307 * *$ & $.267^{* *}$ & $.136^{*}$ & $.350 * *$ \\
\hline & $p$ & .000 & .000 & .000 & .013 & .000 \\
\hline \multirow{2}{*}{ BMI } & r & $.132 *$ & $.141 * *$ & $.114 *$ & -.005 & $.139 *$ \\
\hline & $p$ & .016 & .010 & .037 & .932 & .011 \\
\hline
\end{tabular}

Note: ${ }^{*} p<0.05,{ }^{* *} p<0.01$, EES: Emotional Eating Scale, EWN: Eating When Nervous, ENE: Eating to cope with Negative Emotions, SC: Self Control, CAS: Control Against Stimuli

isolation period of the athletes $(\mathrm{p}>0.05)$.

When the relationship between the POMS and EES total and subscale score averages of the athletes were examined, significant positive correlations were determined between the EES total and all subscale score averages of tension, depression, anger, fatigue, and total POMS score averages. Confusion score mean was correlated positively with other sub-dimension means except CAS (r; 0.38, p; $0.435>0.05$ ), whereas in the vigor sub-dimension, only the EWN mean was negatively correlated ( $\mathrm{r} ;-0.118, \mathrm{p} ; 0.00<0.01$ ), detected. Besides, when the relationship between the BMI means and emotional eating status of the participants was examined, it was determined that there were positive significant relationships between all the other sub-dimensions and EES total score averages except CAS. Among the examined variables, the strongest correlation was found between POMS total and EWN sub-dimension with $\mathrm{r}=$ 0.365 coefficient.

Nervous, ENE: Eating to cope with Negative Emotions, SC: Self Control, CAS: Control Against Stimuli, Total EES:Total Emotional Eating Scale

\section{Discussion}

In literature, many studies have been conducted to identify changes in human mood status [14-16] and eating behaviors in different periods and conditions. However, there has not been any research on the impact of COVID-19 pandemic, which creates a scantiness/limitation that has never been seen in human life, on the emotional and emotional eating behaviors of young university students who are active athletes. Although this situation causes limitations in terms of comparing our results with existing literature, our results may be a pioneer to future studies to be conducted in order to detailed analysis.
The absence of a definitive, effective treatment method developed for COVID-19 brought the concern for the spread of the virus $[8,17]$. This situation made it obligatory to take infection control and security measures during the pandemic period. Although the implementation of "stay home" (social isolation) aimed at restricting social life is a basic security step that can limit infections [18], it has kept the people away from daily routine life and changed their moods and nutritional behaviors.

In the research, while determining the effect of the pandemic process on the emotional state and nutritional behaviors of university athletes, it was evaluated whether there was a difference in terms of professionalism levels (elite / amateur) in athletes. Many studies show that the COVID-19 pandemic period increases the susceptibility to psychological problems such as depression, anxiety and panic disorder as well as physically affecting individuals [19-22]. In the study, it was determined that there was an increase in negative emotional state and emotional eating behaviors in both groups. However, when the total and subscale score averages of the EES and POMS scales of amateur and elite athletes were compared, it was determined that there was no significant difference between the groups although the scores were higher in elite athletes $(\mathrm{p}>0.05)$. Another study on elite and recreational athletes found a significant relationship between athletes' POMS scores and perfectionism approaches [23]. Stirling and Kerr [23] may be an explanation for the high average scores of elite athletes as a result of the research. Also, there was a significant increase in the amount of fluid consumption in elite athletes, and there was a significant relationship between negative mood and emotional eating status sub-dimensions $(\mathrm{p}<0.05)$.

There is a positive correlation between the total EES score of the athletes and the total POMS score and POMS 
sub-dimensions (tension, depression, anger, fatigue, confusion). Increasing negative mood caused an increase in emotional eating behaviors. For the vigor associated with positive emotional state, there is a negative but not significant relationship ( $\mathrm{r} ;-0.78 ; \mathrm{p} ; 0.157>0.05)$ with emotional eating behavior. In his study, Renger determined that total POMS, depression, tension, anger, fatigue, and confusion scores are lower than other athletes and higher vigor scores in athletes with high success levels [24].

While the desire to be weak more common in some sports, where weakness is important, the frequency of eating behavior disorder increases [25], there is a positive relationship between BMI and depression [26], and between athletes' anxiety states and irregular eating behaviors [27]. In the study, there was a positive correlation between BMI and total EES (r; 0.139, p; $0.011<0.05)$ and its sub-dimensions (EWN, ENE, SC), and a negative nonsignificant relationship with the CAS score (r; - 0.05 ; $\mathrm{p}$; $0.932>0.05)$. It was determined that those with higher BMI tend to eat more emotionally. Results support other study results. Increasing the time spent at home caused individuals to change their mood [28], to get more energy in their diet and to consume more fat, carbohydrate, and protein $[18,29]$. In a study investigating the relationship between negative mood and high nutritional intake, it was found that sad mood increased food intake more than happiness [28, 30]. Stress causes individuals to search for food that will provide relief quickly and generally the tendency towards sugary foods increases $[31,32]$. In the study, there was no statistically significant difference between the amount of food consumed during the social isolation period, the number of daily meals, supplement consume and the immune-boost food intake ( $p>0.05$ ). However, when the fluid consumption rates were compared, it was determined that elite athletes increased their fluid consumption and did not change in amateur athletes $\left(X^{2} ; 3657, \mathrm{p} ; 0.04\right)$. It is a pleasing finding that fluid consumption has not decreased. It was determined that the amount of carbohydrate and fat consumption decreased/ did not change during the social isolation period of the athletes but there was an increase in protein consumption. It is thought that avoiding weight gain in reducing fat consumption, and increasing protein consumption, it is thought that protein may be effective in preventing losses that may occur in muscle tissues due to limited physical activity during the stay at home. Carbohydrates with proven effects on athlete's performance are thought to have had an effect on the consumption of athletes at a less / unchanged level during their home period, when they could not train [33].

In addition to the relationship between food and mood, nutrients frequently mentioned from the effect of strengthening the immune system are omega-3 fatty acids [8, 32], vitamin D, zinc [34], prebiotics/probiotics $[35,36]$ and antioxidants, especially vitamin C [37]. It is emphasized that especially foods rich in vitamin $\mathrm{C}$ are both reliable and inexpensive food sources against COVID-19 and should be consumed daily [38]. Various studies have reported that fruits and vegetables rich in micronutrients can improve immune function [37]. It was found that the athletes participating in the study used the most supplements containing vitamin $\mathrm{D}$, multi-vitamin, and omega-3, respectively, to strengthen their immunity against COVID-19. The importance of vitamin D in the athlete's health and performance has been the subject of many studies, especially in recent years $[39,40]$. The attitudes of the young people participating in the study are the reflection of their knowledge on this subject.

\section{Conclusions}

- $\quad$ During the pandemic period, it was determined that there was an increase in negative emotional state and emotional eating behaviors in both groups during the social isolation period.

- Increasing negative emotional state caused an increase in emotional eating behavior.

- When amateur and elite athletes' total and subscale score averages of the EES and POMS scales were compared, it was determined that there was no significant difference between the groups, although the scores were higher in elite athletes.

- There is a positive correlation between the total EES score of the athletes and the total POMS score and POMS sub-dimensions (tension, depression, anger, fatigue, confusion).

- It was determined that those with higher BMI had higher emotional eating behavior scores.

- There is no statistically significant difference was found between the groups between the amount of food consumption, the number of meals per day, supplements consumption, and the immune-boost food intake.

- When the fluid consumption rates were compared, it was determined that the elite athletes increased their fluid consumption and did not change in the amateur athletes.

- In order to strengthen immunity, it was determined that supplements with the most vitamin D, multi-vitamin, and omega-3 content were used respectively.

- It was determined that the amount of carbohydrate and fat consumption decreased/did not change during the social isolation period of the athletes but there was an increase in protein consumption.

\section{Acknowledgement}

We gratefully acknowledge the help of all the participant who took part in the study.

\section{Conflict of interests}

The authors state that there is no conflict of interest 


\section{References}

1. World Health Organization (a). Coronavirus disease (COVID-19) pandemic. [document on the Internet] WHO: 2020 March 19 [cited 2020 May 6]. Available from: https:// www.euro.who.int/en/health-topics/health-emergencies/ coronavirus-covid-19/novel-coronavirus-2019-ncov

2. World Health Organization (b). Coronavirus Disease 2019 (COVID-19) Situation Reports-101. [document on the Internet]. WHO: 2020 April 30 [cited on 6 May, 2020]. Available from: https://www.who.int/emergencies/diseases/ novel-coronavirus-2019/situation-reports

3. Hellewell J, Abbott S, Gimma A, et al. Feasibility of controlling COVID-19 outbreaks by isolation of cases and contacts. Lancet Glob Heal. 2020;8(4):e488-e496. https://doi.org/10.1016/S2214-109X(20)30074-7

4. Anderson RM, Heesterbeek H, Klinkenberg D, Hollingsworth TD. How will country-based mitigation measures influence the course of the COVID-19 epidemic? Lancet, 2020;395(10228):931-934. https://doi.org/10.1016/S0140-6736(20)30567-5

5. Halabchi F, Ahmadinejad Z, Selk-Ghaffari M. Covid-19 epidemic: Exercise or not to exercise; that is the question. Asian Journal of Sports Medicine. 2020;11(1):1-3. https://doi.org/10.5812/asjsm.102630

6. Lippi G, Henry BM, Sanchis-Gomar F. Physical inactivity and cardiovascular disease at the time of coronavirus disease 2019 (COVID-19). European Journal of Preventive Cardiology. 2020;27(9):906-908. https://doi.org/10.1177/2047487320916823

7. Wang $C$, Pan R, Wan X, et al. Immediate psychological responses and associated factors during the initial stage of the 2019 coronavirus disease (COVID-19) epidemic among the general population in China. International Journal of Environmental Research and Public Health. 2020;17(5):1729. https://doi.org/10.3390/ijerph17051729

8. Eskici G. Covid-19 pandemia: Nutrition recommendations for quarantine. Anadolu Kliniği Tip Bilimleri Dergisi-Anatol Clin, 2020;25(1):124-129. https://doi.org/10.21673/anadoluklin.722546

9. Figley CR. Foreword. In International Handbook of Traumatic Stress Syndromes (ed. Wilson, J. P. and Raphael, B.), pp. XVII-XIX. New York: Plenum Press; 1993.

10.Roccella M. Children and coronavirus Infection (Covid-19): What to tell children to avoid posttraumatic stress disorder (PTSD). The Open Pediatric Medicine Journal, 2020;10(1):1-2. https://doi.org/10.2174/1874309902010010001

11.McNair DM, Lorr M, Droppleman, LF. Profile of Mood States. Educational and Industrial Testing Service. San Diego: CA; 1971.

12.SelviY,GulecM,AydinA,BesirogluL.Psychometricevaluation of the Turkish language version of the Profile of Mood States (POMS). Journal of Mood Disorders. 2011;1(4):152-61. https://doi.org/10.5455/jmood.20110902072033

13.Bilgen SŞ. Türkçe Duygusal Yeme Ölçeği gelişstirilmesi geçerlilik ve güvenirliği çalışması [Validity and Reliability of the Turkish Version of the Emotional Eating Questionnaire] (Master Thesis). Üsküdar Üniversitesi Sosyal Bilimler Enstitüsü, İstanbul; 2018. (In Turkish).

14.Beedie C, Terry PC, Lane AM. The profile of mood states and athletic performance: Two meta-analyses. Journal of Applied Sport Psychology. 2000;12(1):49-68. https://doi.org/10.1080/10413200008404213

15.Benjamin CL, Curtis RM, Huggins RA, et al. Sleep dysfunction and mood in collegiate soccer athletes. Sports Health. 2020;12(3):234-240. https://doi.org/10.1177/1941738120916735

16.Graham SM, Martindal RJJ, McKinley M, Connaboy C, Andronikos G, Susmarski A. The examination of mental toughness, sleep, mood and injury rates in an Arctic ultra-marathon. Eur J Sport Sci, 2020;10:1-7. https://doi.org/10.1080/17461391.2020.1733670

17.Ahmadpoor P, Rostaing L. Why the immune system fails to mount an adaptive immune response to a Covid-19 infection. Transpl Int. 2020; 33: 824-825. https://doi.org/10.1111/tri.13611

18.Chen P, Mao L, Nassis GP, Harmer P, Ainsworth BE. $\mathrm{Li}$ F. Coronavirus disease (COVID-19): The need to maintain regular physical activity while taking precautions. J Sport Health Sci, 2020;9(2):103-104. https://doi.org/10.1016/j.jshs.2020.02.001

19.Ahmed MZ, Ahmed O, Aibao, Z. Epidemic of COVID-19 in China and associated psychological problems. Asian J Psychiatr. 2020;51(102092): 1-7. https://doi.org/10.1016/j.ajp.2020.102092

20.Hiremath P, Kowshik S, Manjunath M. COVID 19: Impact of lock-down on mental health and tips to overcome. Asian $J$ Psychiatr. 2020;51:102088. https://doi.org/10.1016/j.ajp.2020.102088

21.HuangY, Zhao N. Generalized anxiety disorder, depressive symptoms and sleep quality during COVID-19 outbreak in China: A Web-based crosssectional survey. Psychiatry Res, 2020;288:112954. https://doi.org/10.1016/j.psychres.2020.112954

22.Li S, Wang Y, Xue J, Zhao N, Zhu T. The impact of COVID-19 epidemic declaration on psychological consequences: A study on active weibo users. Int $J$ Environ Res Public Health. 2020;17(6):2032. https://doi.org/10.3390/ijerph17062032

23. Stirling AE, Kerr GA. Perfectionism and mood states among recreational and elite athletes. Athletic Insight, 2006;8(4):1327.

24.Renger RA. Review of the profile of mood states (POMS) in the prediction of athletic success, J Appl Sport Psychol. 1993;5(1):78-84. https://doi.org/10.1080/10413209308411306

25.Mathisen TF, Sundgot-Borgen J. Mental health symptoms related to body shape idealization in female fitness physique athletes. Sports (Basel), 2019;147(11):E236. https://doi.org/10.3390/sports7110236

26.Lazarevich I, Irigoyen Camacho ME, VelázquezAlva MDC, Zepeda M. Relationship among obesity, depression, and emotional eating in young adults. Appetite. 2016;1(107):639-644. https://doi.org/10.1016/j.appet.2016.09.011

27.Costarelli V, Stamou D. Emotional intelligence, body image and disordered eating attitudes in combat sport athletes. Journal of Exercise Science \& Fitness. 2009;7(2):104-111. https://doi.org/10.1016/S1728-869X(09)60013-7

28.Serin Y, Sanlier N. Emotional eating, the factors that affect food intake, and basic approaches to nursing care of patients with eating disorders. J Psychiatric Nurs. 2018;9:135-146. https://doi.org/10.14744/phd.2018.23600

29.Moynihan AB, van Tilburg WA, Igou ER, Wisman A, Donnelly AE, Mulcaire JB. Eaten up by boredom: consuming food to escape awareness of the bored self. Front Psychol, 2015;1(6):369. https://doi.org/10.3389/fpsyg.2015.00369

30.Evers C, Adriaanse M, de Ridder DT, de Witt Huberts JC. Good mood food. Positive emotion as a neglected 
trigger for food intake. Appetite. 2013;68:1-7. https://doi.org/0.1016/j.appet.2013.04.007

31.Muscogiuri G, Barrea L, Savastano S, Colao A. Nutritional recommendations for COVID-19 quarantine. Eur J Clin Nutr. 2020;14:1-2. https://doi.org/10.1038/s41430-020-0635-2

32.Özenoğlu A. Relationship between mood, food and nutrition. ACU Sağllk Bil Derg. 2018;9(4):357-365. https://doi.org/10.31067/0.2018.56

33.Fink HH, Mikesky AE. Practical Applications in Sports Nutrition. Fifth Edition. Jones and Bartlett Learning, USA; 2018.

34.Arslan M. The relationship between vitamin $\mathrm{D}$ and chronic obstructive pulmonary disease. Sağllk Akademisi Kastamonu. 2020;5(1):65-77. https://doi.org/10.25279/sak.423115

35.Akpınar DD, Türköz BK. Probiotic-human immune system interactions. Food and Health. 2019;5:265-280. https://doi.org/10.3153/FH19027

36.Lee IC, Tomita S, Kleerebezem M, Bron PA. The quest for probiotic effector molecules-unraveling strain specificity at the molecular level. Pharmacol Res, 2013;69(1):61-74. https://doi.org/10.1016/j.phrs.2012.09.010

37.Chandra RK. Effect of vitamin and trace-element supplementation on immune responses and infection in elderly subjects. Lancet, 1992;340:1124-1127. https://doi.org/10.1016/0140-6736(92)93151-c

38.Kalantar-Zadeh, K, Moore LW. Impact of nutrition and diet on COVID-19 infection and implications for kidney health and kidney disease management. JRen Nutr. 2020;30(3):179-181. https://doi.org/10.1053/j.jrn.2020.03.006

39.Sikora-Klak J, Narvy SJ, Yang J, Makhni E, Kharrazi FD, Mehran N. The Effect of Abnormal Vitamin D Levels in Athletes. Perm J. 2018;22:17-216. https://doi.org/10.7812/TPP/17-216

40.Pritchett K, Pritchett RC, Stark L, Broad E, LaCroix M. Effect of vitamin D supplementation on $25(\mathrm{OH})$ D status in elite athletes with spinal cord injury. Int $J$ Sport Nutr Exerc Metab. 2019;29(1):18-23. https://doi.org/10.1123/ijsnem.2017-0233

\section{Information about the authors:}

Gökmen Özen; (Corresponding Author); https://orcid.org/0000-0001-5756-653X; gokmenozen44@gmail.com; Department of Physical Education and Sports Teaching, Faculty of Sport Sciences, Çanakkale Onsekiz Mart University; Çanakkale, Turkey.

Günay Eskici; https://orcid.org/0000-0002-4349-4704; dytgunay@gmail.com; Department of Coaching Education, Faculty of Sport Sciences, Çanakkale Onsekiz Mart University; Çanakkale, Turkey.

Hüseyin Ö. Yurdakul; https://orcid.org/0000-0001-6879-3658; hoyurdakul@gmail.com; Department of Physical Education and Sports Teaching, Faculty of Sport Sciences, Çanakkale Onsekiz Mart University; Çanakkale, Turkey.

Hürmüz Koç; https://orcid.org/0000-0003-1588-7583; hurmuzkoc@gmail.com; Department of Coaching Education, Faculty of Sport Sciences, Çanakkale Onsekiz Mart University; Çanakkale, Turkey.

Cite this article as:

Özen G, Eskici G, Yurdakul HÖ, Koç H. Assessment of the impact of COVID-19 pandemic on emotional and nutritional status of university athletes. Physical Education of Students, 2021;25(1):43-50.

https://doi.org/10.15561/20755279.2021.0106

This is an Open Access article distributed under the terms of the Creative Commons Attribution License, which permits unrestricted use, distribution, and reproduction in any medium, provided the original work is properly cited http://creativecommons.org/licenses/by/4.0/deed.en

Received: 17.12 .2020

Accepted: 04.02.2001; Published: 26.02.2021 